\title{
The effect of tourism education on students' entrepreneurial vocation
}

This paper aims to examine how higher education affects entrepreneurial vocation in a very specific segment, namely university education in tourism. We used a theoretical approach based on the psychological foundations of intentional theory to analyse a sample of 122 graduate and undergraduate university students in tourism from the perspective of higher education. The results show the differential effect of curricular and extracurricular activities on intentions, attitudes and behavioural control, while there is very little effect on the development of entrepreneurial competencies.

\section{Introduction}

The study of tourism, which has a long tradition as a university degree course, is one of the few sectors with specific training (see for example the UK case of Busby and Huang (2012) and Fidgeon (2011)).With the entry of universities into tourism as a field of study, and more recently with the impact of the European Higher Education Area, these degree courses have undergone a significant transformation and a spectacular advance at both the graduate and postgraduate levels. Another development worth noting is the launch of doctoral programmes in this key sector.

In the early 1990s, tourism studies combining tourism with business were considered to be the ideal curriculum model (Tribe, 2000b): a vocational discipline providing the required business skills and knowledge of the market (Koh, 1995; Tribe, 1997, 2000a; Israeli, 2014; Solvoll et al., 2015). Haywood and Maki (1992), and Koh (1995) noted that the tourism industry needed practical and general capabilities such as computer skills, human resource management, managerial accounting and service quality management. Koh (1995) proposed the combination of vocational modules (hotel and restaurant operations, principles of tourism development, travel and tourism industry and others) with business and entrepreneurship modules (marketing, accounting, entrepreneurship and innovation and so on) and skilldeveloping modules (such as written communication skills, interpersonal relation skills and more) in the tourism curriculum. Airey and Tribe (2000) reported the doubts as to whether tourism and hospitality education prepared students for thinking critically and working in the real world, while Kirby (2005), Li (2008) and Echtner (1995) noted even greater concerns with regard to the knowledge and skills taught to develop entrepreneurial vocation. 
The importance of the tourist industry in the economy is well known (Anderson, 2007; Oh et al., 2007). In this context, universities are developing training activities in the field of tourism, with the aim of training future managers of tourism enterprises (Carlbäck, 2012; Rodriguez et al., 2012). However, little research has been done on the efficacy of these activities, and there are doubts as to the effectiveness of this training for developing entrepreneurial vocation in tourism students (Echtner, 1995; Tribe, 1997; Airey and Johnson, 1999; $\mathrm{Li}, 2008)$. The authors point out that the modular training that allows users to combine vocational and business modules, combined with the need to adapt the syllabus to the world of business, and the autonomy of the universities, has led to a wide assortment of programmes which have differing degrees of success.

Our paper is intended to address the research question of whether the entrepreneurial vocation of university students of tourism is affected by the activities imparted by universities within their training programmes. We propose a theoretical approach based on the psychological foundations of intentional theory (Shapero and Sokol, 1982; Ajzen, 1991), and considering higher education activities as being either "curricular" or "extracurricular". Curricular activities involve participation in formal learning scenarios involving the teaching of skills and attitudes, while extracurricular activities include support for cognitive, informative/formative and instrumental activities. We addressed two questions: first, how tourism education develops entrepreneurial initiative among undergraduate and master's students; and how curricular and extracurricular activities have an effect on the intentions, attitudes and the capabilities for developing entrepreneurship. Second, we consider the effectiveness of curricular and extracurricular activities in developing competencies in entrepreneurship.

\section{Conceptual framework}

\subsection{Entrepreneurship and higher education}

The relationship between higher education institutions and entrepreneurship continues to be under debate. As indicated by Palmberg (2008), Collins et al. (2005), and Ertuna (2011) universities should play a pivotal role in developing the entrepreneurial vocation of university students. Research into the role of universities in developing entrepreneurial vocation has focused primarily on determining whether people can be taught to be entrepreneurs (Aldrich and Martínez, 2001; Gartner, 1988; Rae, 2005; Nicolau and Shane, 
2009; Booth et al., 2009; Guerrero and Urbano, 2012). It is generally assumed that some skills are genetic whereas others can be developed, although there is a consensus that the core competencies involved in entrepreneurial behaviour can effectively be developed in education-regulated settings (Barón, 2002; Gartner, 1988; White, Thornhill and Hampson, 2006; Anderson et al., 2008; Morris et al., 2013). In this context, these authors highlight the importance of developing a set of activities that include subjects related to entrepreneurship such as starting a business or making business plans- in the curricular contents of the various course syllabuses. Liñan (2007), Soutaris et al. (2007), and Sanchez (2013) consider the need to develop a training model based on the combination of organised education and the institutional support of universities. The authors highlight two components: one curricular, which fulfils the requirements of contents and coursework in the different degrees; and a second involving extracurricular activities related to actions designed to provide facilities and support and/or aid for entrepreneurship.

A second body of research has focused on the efficacy of the actions to foster entrepreneurial vocation (for example, Autio et al., 1997). Boissin et al. (2009a, b) conclude that the inclusion of subjects related to entrepreneurship in the syllabus appears to increase the inclination to entrepreneurship by the participants. Galloway and Brown (2002), in a research work with university students, found evidence that participation in subjects involving the creation of companies was related to participants' entrepreneurial intention. In general, studies confirm that university education has a positive influence on the acquisition of skills and competences required to develop an entrepreneurial project (Liñan and Chen, 2009; Boissin et al, 2009a; Sanchez, 2013). However, Garavan and O’Cinneide (1994) report that education can influence entrepreneurship in a positive or negative way. Peterman and Kennedy (2003) also note that formal education does not encourage entrepreneurial vocation, but instead leads to conformity and a reduced tolerance for ambiguity, lowering students' capacity for creative thinking and suppressing their creativity and entrepreneurial spirit. Laukkanen (2000) stresses that higher education institutions not only make their students too analytical, overly conscious of problems and risk-averse, but also scare their students off starting new business projects. Grebel et al. (2003), and Ertuna and Gurel (2011) note the controversy aroused by the teaching of entrepreneurial vocation as a subject.

Despite the numerous actions implemented, there is still no consensus as to which of the different theoretical models to apply to develop entrepreneurship in universities (Brazeal and 
Herbert, 1999; Hindle and Cutting, 2002). According to Krueger and Brazeal (1994) entrepreneurial training should improve the feasibility and desirability of creating a business. Laukkanen (2000) proposes the creation of an educational system based fundamentally on generating entrepreneurship skills centred on the individual; that is, a system that incentivises the development of business models that lead to the creation, development and maintenance of companies over time. Morris et al. (2013) and Sanchez (2013) highlight the importance of developing thinking skills (which enable students to analyse, compare, contrast, criticise and evaluate) and creative skills (with which to imagine or discover) in educational processes. However, there is little indication within the educational process of the ideal teaching resources to enable the transmission of the knowledge and values that encourage the entrepreneurial spirit (Gurel et al., 2010).

2.2 Curricular and extracurricular activities in the development of entrepreneurial vocation

Gibb (2005) and Collins et al. (2004) classify the activities implemented by the universities into curricular -that is, those structured within the syllabuses, and which include a teacher, subject content and a teaching methodology-, and extracurricular activities such as lectures by entrepreneurs, talks and discussions, visits to companies, publication of magazines and materials in general, and other actions that convey the university's vocation and commitment to the values of entrepreneurship.

On the subject of the impact of curricular activities on entrepreneurial vocation, Zabalza (2011) points out that all degree courses have a set of general objectives and skills that are in turn structured into a series of subjects, each one of which has its own aims and contents. According to this author, some subjects are more geared than others to developing the skills that are clearly involved in entrepreneurship, such as those dealing with financial topics, strategy, leadership and organisational changes. Similarly, Sanchez (2013) analyses the results of courses for entrepreneurs and reports that the development of educational programmes has an impact on skills for entrepreneurship such as risk-taking, self-efficacy, and proactiveness. The teacher's work has also been highlighted as a key element in the process of teaching entrepreneurship in education (Laukkanen, 2000). Laukkanen (2000) notes that the impact of the adequate methodology varies depending on the teacher's skill in putting it into practice. The combination of methodology and teacher has been identified as a key element in developing entrepreneurial skills and aptitudes (Anderson and Jack, 2008). 
Rae (2005), Nabi and Holden (2008), and Saarinen and Ursin (2012) indicate that the integration of theoretical and practical teaching using the case method, group work and enterprise games, for example, in addition to entrepreneurial experiences in the form of lectures by entrepreneurs, visits to companies and talks on entrepreneurship by outside speakers, all have a positive impact on entrepreneurial vocation.

In terms of extracurricular activities, Gidds (2005) notes that the institution's efforts are perceived within a culture that represents a form of action that presupposes particular behaviours. Kirby (2005), Maskell and Robinson (2002), Etzkowitz (2004) and Saarinen and Ursin (2012) suggest the concept of the entrepreneurial university, in which the design of a set of perfectly coordinated actions with a systemic approach makes entrepreneurial behaviour the norm rather than the exception. The idea is that entrepreneurship should be the inspiration underlying all its activities - not only training activities-, in an environment of creation and innovation. Etzkowitz (2004) describes the entrepreneurial university as one that takes actions aimed at transferring knowledge to society and incorporating this experience into professional training, generating a biunivocal model that produces a feedback loop in all its different areas. According to Kirby (2005), an entrepreneurial university has the capabilities to innovate, discover and exploit opportunities in the environment, promote teamwork, assume risks and respond to challenges. This author also believes that to achieve these goals the university must focus on fulfilling its mission in the broadest sense, and should include work in teaching, research and entrepreneurship.

\subsection{Model: Tourism education and entrepreneurship vocation}

Education in tourism and hospitality has a multidisciplinary nature, and combines vocational education with business and management skills (Tribe, 2000b; Airey and Tribe; 2005; Fidgeon, 2010; Solvoll et al., 2015); this raises the research question of whether tourism studies develop entrepreneurial vocation.

Most of the work done by higher education institutions to develop entrepreneurial vocation assumes a psychological approach (Theory of Planned Behaviour, Azjen, 1991; 2002), and involves encouraging the intentions, attitudes and behavioural control of university students (Boissin et al., 2009a, b; Autio et al., 1997). The cognitive psychological approach provides a useful perspective to analyse the phenomenon of entrepreneurial decision through the study of perceptions and intentions. The conceptual foundation of the psychological processes underlying entrepreneurial intention is based on the model of 
Shapero and Ajzen (Ajzen, 1991), an approach in which intention reflects the motivational factors that influence behaviour (Ajzen, 1991, p. 181), and is seen as the immediate antecedent of behaviour (Kolvereid, 1996; Krueger, 2000). The formation of an intention is influenced by three antecedents: a favourable or unfavourable evaluation of the behaviour; beliefs concerning the expectations of important reference groups to perform or not perform the behaviour; and the perceived ability to perform the behaviour. The first question is therefore:

Research Question 1: Does education in tourism affects students' intentions, attitudes and behavioural control?

A second group of research takes the perspective of higher education (Laukkanen, 2000; Morris et al., 2013; Sanchez, 2013). These works study the effect of curricular and extracurricular activities on entrepreneurial competencies. Morris et al. (2013, p. 353) defines the notion of competency as follows: "Competency refers to the knowledge, skills, attitudes, values, and behaviours that people need to successfully perform an activity". Sanchez (2009), Rasmussen et al. (2011) and Morris et al. (2013) divide entrepreneurial competencies into those of psychology (self-efficacy, proactiveness, and risk-taking), relation and management (leadership and teamwork), and knowledge competencies. The second question is therefore:

Research Question 2: How do curricular and extra-curricular activities affect students' entrepreneurial competencies?

-Insert Figure 1 about here-

\section{Method}

\subsection{Sample}

For the empirical study we used a convenience sample based on undergraduate and graduate students in the bachelor's degree in Tourism at the Madrid Complutense University and the master's degree in Hotel Management and Administration at the Madrid Polytechnic University, two of the largest universities in Spain. Our empirical study was conducted by means of a questionnaire, previously checked, with a group of ten students. The definitive questionnaire was distributed to all the tourism students during class time. We followed the principles of the total design method (Dillman, 1978). All the questionnaires were given in the same week, in May 2014. A total of 122 valid questionnaires were obtained from 95 
undergraduate and 27 postgraduate students; the maximum population size was 525 registered students.

The analysis of the sample as a whole shows that there are substantially more female students $(68 \%)$ than male $(32 \%)$. The ages of the participants vary from undergraduate students with an average age of 21.5 years, to master's students with 25.9. The minimum age is 19 and the maximum 39. Spain is the country of origin for most of the students (seven students did not indicate their country of origin) -almost $67 \%$ of the respondents. Foreign students represent $27 \%$ of the sample. The number of foreign students is very high, which clearly indicates the appeal of specialised training in tourism. Finally, to the question of whether the respondent works or has worked, $36 \%$ answered no, whereas a high proportion $64 \%$ - said yes, mostly as company employees. This percentage is higher in the case of master's students, $81 \%$ of whom said they had worked previously or were working at the time.

\subsection{Measures}

Following Souitaris et al. (2007), Kibler et al. (2014), and Kolvereid (1996) the variables intention, attitude and behavioural control have been measured engaging in activities to start a business. Following Kilber et al. (2014), intention was measured as: "I intend to take steps to start a business in the next 12 months" (disagree/agree). Attitude was measured as: "For me, taking steps to start a business in the next 12 months would be unpleasant/attractive". Behavioural control was measured as: "If I wanted to, I could take steps to start a business in the next 12 months" (disagree/agree). Each construct was measured using a seven-point rating scale (Cronbach alpha: 0.72 ).

The European Reference Framework (Recommendation 2006/962/CE, section 2.2.1) considers that curricular activities refer to students' participation in formal learning situations involving the teaching of skills and attitudes related to entrepreneurship competencies. In order to assess the influence of the students' current studies, they were asked which issues had most influence on their entrepreneurship motivations. Following Nabi and Holden (2008), Laukkanen (2000), Souitaris et al. (2007), and Pittaway et al. (2009), we measure the following items: 1) subject content (Modules); 2) coursework and practical work (Coursework); 3) influence of the teaching staff (Faculty); 4) development of practical entrepreneurial cases (Cases); 5) teamwork (Teamwork); 6) talks and lectures by entrepreneurs in class (Entrepreneurial lectures); and 7) teaching methodology 
(Methodology). Each construct was measured using a seven-point rating scale, where 1 was not very important and 7 was very important (Cronbach alpha: 0.89)

Following Ramussen and Sorheim (2006) and De Faoite et al. (2003), we measured extracurricular activities as support for cognitive, informative/formative and instrumental activities to materialise entrepreneurial intention. We adapted the following items: 1) Lectures and seminars on entrepreneurship (Conferences); 2) Visits to companies (Visiting); 3) Simulators and business games (Business games); 4) Degree programme structure (Programme); 5) Facilities and infrastructures for entrepreneurship (Facilities); and 6) Spirit and values in entrepreneurship in the university (Spirit and values). Each construct was measured using a seven-point scale, where 1 denoted low importance and 7 high importance (Cronbach alpha: 0.85)

We followed Sanchez (2009), Rasmussen et al. (2011), and Morris et al. (2013) in adapting entrepreneurial competencies from those of psychology (self-efficacy, proactiveness, and risk), relation and management (leadership and teamwork), and knowledge, and we considered these items: 1) Power of decision about my business project (Decision); 2) Effort and concentration until success is achieved (Concentration); 3) Analysing the diverse solutions and making the most suitable decision (Analysis); 4) Working in groups, identifying the skills of each member in order to complement each other and build a collaborative atmosphere (Teamwork); 5) Taking the initiative, defining goals (Initiative); 6) Working as long as necessary to complete the project (Tenacity); 7) New ways to make things (Creativity); 8) Self-confidence (Self-confidence); 9) Leadership to convince and make people join your project (Leadership) 10) You like to take risks (Risk); and 11) The education required to undertake a business (Knowledge). Each construct was measured using a sevenpoint rating scale, where 1 denoted low agreement and 7 high agreement (Cronbach alpha: $0.86)$.

\section{Analysis and results}

Table 1 shows how tourism students perceive entrepreneurial attitude, behavioural control and intention based on the results of the first research question as to whether tourism studies develop entrepreneurial initiative. In general we see high values of entrepreneurial vocation for both undergraduate and master's students. In more detail, it is worth noting that entrepreneurial attitude is approximately five points on a scale of seven (4.85 for 
postgraduate students and 5.15 for undergraduates), whereas the behavioural control to carry out an entrepreneurial project is 4.27 (3.81 for postgraduates; 4.41 for undergraduates). The results for entrepreneurial intention show this to be more pronounced in master's students (3.29) than in undergraduates (3.00). In order to verify our data, and following the Denzin method (1978), we compared our results with other studies of university students. In their study on university students in France and the US, Boissin et al. (2009b) found that higher education has a positive effect on both intentions and attitudes and behavioural control. De Faoite et al. (2003) obtained the same results in a study of university students in Ireland and Holland. Souitaris et al. (2007) found a positive relationship between education and intention in a sample of non-business students, in their case engineering students. Autio et al. (1997), in their comparison of university students in Asia, Scandinavia and the US, found differences between attitudes and intention, and reported that education exerted a greater effect on attitude than on intention. We can therefore corroborate the validity of our results and extract a preliminary conclusion, namely that university education has a positive effect on entrepreneurial vocation. In second place, our results confirm the studies that indicate that university education enables and creates attitudes for entrepreneurship. However, it does very little to foster intentions, as a prior step to the decision to develop an entrepreneurial project (Boissin et al., 2009b; Autio et al., 1997). On this point the literature indicates the need for extracurricular activities (incubators, funding facilities, information centres and so on) to facilitate the conversion of attitudes to intentions (Guerrero and Urbano, 2012). The analysis of differential behaviours reveals differences between the two groups of educational levels (undergraduate and master's). The attitude and behavioural control to create a business is greater in undergraduate students. We can find an explanation of this fact in the literature, based on what Baron and Ensley (2006) call optimism-bias. It has been demonstrated that in a situation of uncertainty, novice entrepreneurs tend to overestimate their capacity and the potential results to be obtained (Baron and Ensley, 2006). Our results show a greater definition of the entrepreneurial project among postgraduate students than undergraduate students, thus confirming the empirical studies that show that the impending termination of studies is a key factor in the intention to create a company (Laukkanen, 2000; De Faoite et al., 2003; Fayolle et al., 2006). We conducted a MANOVA analysis to establish whether there are significant differences between the two groups. The results reveal no significant 
differences between the two, meaning they can be considered as one homogeneous group (see Table 1).

Insert Table 1 about here

Table 2 shows in greater detail the results of curricular activities on entrepreneurial vocation. The average values range between 4.25 and 5.65 for undergraduates and 4.74 and 5.37 for master's students. It is worth noting the substantial effect of the teacher and teaching on the development of entrepreneurial vocation in the two groups analysed (5.67 undergraduates and 5.37 master's). Our results are in line with the literature on higher education and entrepreneurship which underlines the importance of the teacher in developing entrepreneurial vocation (Laukkanen, 2000; Nabi and Holden, 2008; Liñán, 2008). Differential behaviour can also be seen between the two groups analysed. Undergraduate students tend to rate the content of the module and the coursework more highly. However master's students give a more positive rating to the teaching methodology, teamwork, cases and talks by entrepreneurs. Laukkanen (2000), Fayolle et al. (2006) and Booth et al. (2009) obtained similar results, highlighting the importance of differentiating the two types of teaching. We then carried out a MANOVA analysis to verify whether these differences were significant, and our results show that they are not (see Table 2). However, we should point out that although not significant, these findings reinforce the argument for the need for differential educational and institutional treatment for graduates and undergraduates, as in the well-known case of business schools versus universities.

Insert Table 2 about here-

Table 3 shows that the impact of extracurricular activities on entrepreneurial vocation is lower in all activities in master's students (mean: 4.55 and 3.5) than in undergraduates (mean: 5.62 to 4.21). Similarly, Guerrero and Urbano (2012) indicate that the extracurricular activities provided by universities have little impact on entrepreneurial vocation. We can therefore conclude that students have a low perception of universities' contribution to entrepreneurial spirit and values. De Faoite et al. (2003), Laukkanen (2000) and Booth et al. (2009) found differences in the effect of universities on entrepreneurial values and spirit among students, with experience being a factor that moderates this perception. In order to test whether these differences are significant, we carried out a MANOVA analysis which, as shown in Table 3, does not confirm the difference between both groups. 
Our second research question concerns the effect of curricular and extracurricular activities on the entrepreneurial competencies required by tourism students. We first analysed the acquisition of competencies during their education (see Table 4). We observed values higher than 4 in both groups, except for the competency dealing with knowledge in starting a business, where we obtained values below 4 in both groups, with no significant differences between the groups, as shown by the MANOVA results. Moreover, results of the correlation analysis (Tables 5 and 6) indicated that the curricular and extracurricular activities were both positively and significantly correlated with competencies. To estimate the causal relation between curricular and extracurricular activities in competencies we conducted an analysis of Structural Equation Models (SEM), using AMOS 21. Tables 7 and 8 show the results for the effect of curricular and extracurricular activities on competencies for entrepreneurship, obtaining an acceptable level of fit. This suggests that the proposed models explain or fit the data quite satisfactorily (SEM Model 1, curricular competencies: Chi-square $=533.434$; degrees of freedom $=110$; probability level $=.000$; SEM Model 2, extra-curricular competencies: Chi-square $=686.417$; degrees of freedom $=113$; probability level $=.000$ ) . The effect of curricular activities on competencies is heterogeneous, and thus teamwork, faculty and module content have a positive and significant impact on competencies. However, educational methodology has a significant negative impact on several competencies, an interesting and disturbing result that reveals how tourism students perceive educational methodologies. We also observed that the use of cases has no impact on any of the competencies; and practical exercises in class and conferences have very little. We can therefore surmise that competencies are developed based on class content, the faculty and teamwork. We can assert that curricular activities develop interactive competencies such as leadership and teamwork; and to lesser extent psychological competencies such as selfefficacy, proactiveness and risk-taking. A worrying result is that curricular activities have no impact on the knowledge acquired to develop a business. As indicated by Echtner (1995), this finding can be attributed to the fact that training in tourism develops capabilities to work with others and for self-employment. Another argument can be found in Tribers (2000), who highlights the difficulty of compatibilising common goals with modular training. In general we observed little impact of extracurricular activities on competencies. Conferences and facilities have a major impact on the various competences, whereas spirit and institutional 
culture have a negative impact. This fact also illustrates the universities' facilities and culture towards entrepreneurship.

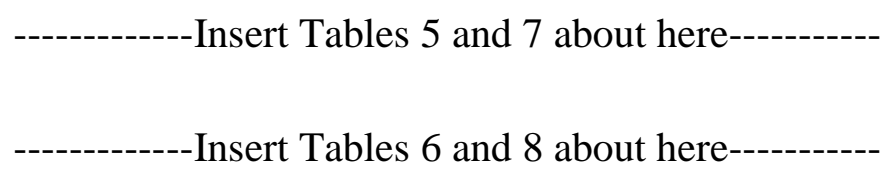

Because our dependent and independent variables were obtained using the same survey instrument, our results may be affected by common-method bias. To address this issue, the items in the questionnaire were arranged so the dependent variable followed, rather than preceded, the independent variables, and we guaranteed response anonymity (Podsakoff et al., 2003). We tested the existence of the Common Method Variance (CMV) in our study and also performed Harman's single-factor test (Harman, 1967) to address the issue of commonmethod bias statistically. If there is a significant amount of common-method bias in the data, a factor analysis of all the variables in the model will generate a single factor, or one general factor that accounts for the majority of the covariance among the measures. Unrotated factor analysis using the eigenvalue-greater-than-one criterion revealed the first factor, which explained 34.062\% (SEM: curricular competences) and 32.392\% (SEM: extra-curricular competences) of the variance, thus suggesting the absence of common-method bias, as its value is below 50\% (Harman, 1967). However, we verified there were no variations in regression weights over 0.200 by adding a Common Latent Factor (CLF). The results gave variations lower than that figure and our results can therefore be considered acceptable (Harman, 1967; Podsakoff et al., 2003).

\section{Conclusions and discussion}

The contribution of this paper is to analyse whether the entrepreneurial vocation of university tourism students is influenced by the various training and institutional activities carried out by the universities. The first conclusion reveals a differential effect of curricular and extracurricular activities on the intention, attitudes and behavioural control of tourism students, without any significant difference between the study levels analysed (undergraduate and postgraduate). The second conclusion of our study is that curricular activities have an effect on the entrepreneurial competencies of tourism students. However it is not clear how these activities act and direct the students' action to the different types of competencies. It 
can be concluded that extracurricular activities have a low level of impact on the development of entrepreneurial competencies.

The main conclusion is the need to continue developing actions and policies aimed at enhancing the entrepreneurial vocation of young university students in the tourism sector. Below we outline certain proposals by decision groups and action capacity in the tourist education sector. The following chart shows a summary of the actions proposed.

-Insert Figure 2 about here

Following Enterprise General Direction (2008), we propose the development of training programmes focused on the target group as a policy recommendation. Following Enterprise General Direction (2008) indicates the importance of noting that both curricular and extracurricular activities should cover the full spectrum of competencies needed for the development of attitudes and behavioural control for entrepreneurship. The education authorities must implement policies that promote the inclusion of these activities in the training programmes, and the universities should be responsible for their scheduling and creation.

The acquisition of skills for managing new entrepreneurial ventures in tourism must be approached with technical knowledge based on management skills and techniques and the personal and interpersonal skills of the promoters. A variety of teaching methodologies should therefore be developed and applied to complement the inclusion in the core curricula of modules on entrepreneurship (Morris, 2013; Sanchez, 2013). Within a conceptual framework that provides the ideal basis for the launch of the idea, activities must be developed for experiential, problem-based and interactive learning (De Faoite et al., 2003). The following learning tools are proposed: sandwich courses and internships, preferentially with companies in the tourist sector, which must provide programmes of practical work experience genuinely consisting of hands-on training, rather than simply a cheap form of labour. The companies must be totally committed in this aspect.

Research by university students has not received any specific attention in the non-doctoral area, and the field is therefore wide open for its development and articulation through small group projects involving students writing and discussing papers or essays, and individual research projects, particularly using the action research approach, which encourages the search for opportunities and acquisition of action skills. Project-based learning methodologies 
are seen as being very suitable for developing the following capabilities, which are closely linked to entrepreneurship (Ertuna and Gurel, 2011): searching for and structuring information, teamwork, independent learning, time planning, project work and the ability to express it correctly. Saarinen and Ursin (2012) point to the development of programmes that encourage learning based on problems and projects, a characteristic of so-called "learning-bydoing" education. We can therefore observe a training mix of active learning and traditional teaching. Analysis and problem-solving tools, interpersonal skills, negotiation and conflict resolution techniques, among others, are necessary tools for business activity, according to Laukanen (2000). In agreement with Healy (2005), we consider it necessary to prioritise the exploration and development of disciplinary spaces where research and teaching can be linked.

Although most universities and their teaching spaces were designed with the lecture model in mind, universities and authorities must not only develop this new model but encourage its genuine implementation, based on the students' work and their own personal development, rather than on the educator's work alone. Thus classic programmes which mainly impart knowledge of business and its related topics contribute little to developing entrepreneurial skills. Analytical skills must be enhanced by encouraging students to apply what they have learnt previously and to engage in critical thinking,

Another aspect revealed by our results is the interaction between curricular content and the modularity of tourism studies. The genuine development of entrepreneurial spirit must be promoted by educational centres and by a society that sees its governors as supporting the creation of new businesses. It is therefore recommended that universities should offer different subjects that require the mandatory study of what we propose to call entrepreneurial credits; that is to say, academic credits oriented to enterprise creation. These credits must include both the theory and the acquisition of management, leadership and personal skills. Therefore, and following Koh (1995) and Tribe (2002), the curricular content should rest on three different cornerstones: vocational modules, entrepreneurship models and skills modules ${ }^{1}$.

\footnotetext{
${ }^{1}$ It is important to note that this study does not include three important aspects of the vocational development of entrepreneurial spirit, namely academic flexibility, faculty profile and the multidisciplinary of the educational focus (see for example, Enterprise General Direction, 2008).
} 
As another means of encouraging entrepreneurial spirit, the academic and financial authorities and the university centres must provide students and society as a whole with extracurricular activities that encourage entrepreneurial intention and the actual creation of companies. Universities should develop a range of strategies, structures and an organisational culture geared to enhancing creativity and entrepreneurial experience, and strategies for entrepreneurial incentives. One of the best ways to reinforce this strategy is to promote strong collaborative agreements between the universities and industry. Finally, we believe that these arrangements should address certain key aspects, such as the development of information centres, infrastructures and material resources.

Our work contributes a series of findings that are both theoretical and of use for policymakers. Our first contribution concerns the debate on the content and approach of tourism education programmes (Gurel et al., 2010; Airey and Tribe, 2000), and broadens their scope to encompass a third way as indicated by Echtner (1995), namely the need to combine vocational and professional training with training in entrepreneurship. The second contribution deals with the debate on the role of universities and the development of entrepreneurial vocation (Laukkanen, 2000). More specifically, we examine the efficacy of curricular and extracurricular activities in developing entrepreneurial intentions and skills. Our work concurs with the new recommendations for extending the entrepreneurial training to careers other than business and marketing.

\section{References}

Airey, D. (2002). Growth and change in tourism education. In B. Vukonic, \& N. Cavlek (Eds.), Rethinking of education and training for tourism (pp. 13-22). Zagreb: University of Zagreb, Graduate School of Economics and Business.

Airey, D. \& Johnson, S. (1999). The content of tourism degree courses in the UK. Tourism Management, 20, 229-235.

Airey, D. \& Tribe, J. (Eds.). (2005). An international handbook of tourism education. Oxford: Elsevier.

Ajzen, I. (1991). The theory of planned behavior. Organizational Behavior and Human Decision Processes, 50, 179-211.

Andersson, T. D. (2007). The tourist in the experience economy. Scandinavian Journal of Hospitality and Tourism, 7(1), 46-58.

Anderson, A. R. \& Jack, S. L. (2008). Role typologies for enterprising education: The professional artisan? Journal of Small Business and Enterprise Development, 15, 259273. 
Autio, E., Keeley, R. H., Klofsten, M., \& Ulfstedt, T. (1997). Entrepreneurial intent among students: Testing an intent model in Asia, Scandinavia and USA. Frontiers of Entrepreneurship Research, Babson Conference Proceedings. Boston, MA.

Baron, R. (2006). Opportunity recognition as pattern recognition: how entrepreneurs connect the dots" to identify new business opportunities. Academy of Management Perspectives, 20, 104-119.

Baron, R. A. (2002). OB and entrepreneurship: The reciprocal benefits of closer conceptual links. In B. Staw and E. Kramer (Eds.), Research in Organizational Behavior, 225-269.

Baron, R. \& Ensley, M. (2006). Opportunity recognition as the detection of meaningful patterns: evidence from comparisons of novice and experienced entrepreneurs. Management Science, 52, 1331-1344.

Belhassen, Y. \& Caton, K. (2011). On the need for critical pedagogy in tourism education. Tourism Management, 32, 1389-1396.

Boissin, J.P., Chollet, B., \& Emin, S. (2009a). Les déterminants de l'intention de créer une entreprise chez les étudiants : un test empirique. M@n@gement, 12(1), 28-51.

Boissin, J.P., Branchet, B., Emin, S., \& Herbert, J. (2009b). Students and Entrepreneurship: A Comparative Study France - United States, Journal of Small Business and Entrepreneurship, 22(2), 101-22.

Booth, A., McLean, M. \& Walkerb, M. (2009). Self, others and society: a case study of university integrative learning. Studies in Higher Education, 34(8), 929-939.

Busby, G. \& Huang, R. (2012). Integration, intermediation and tourism higher education: Conceptual understanding in the curriculum. Tourism Management, 33, 108-115.

Carlbäck, M. (2012). Strategic entrepreneurship in the hotel industry: The role of chain affiliation. Scandinavian Journal of Hospitality and Tourism, 12(4), 349-372.

Collins, L., Hannon, P.D. \& Smith, A. (2004). Enacting entrepreneurial intent: the gaps between student needs and higher education. Education+Training, 46(8-9), 454-63.

De Faoite, D., Henry, C., Johnston, K., \& Sijde, P. V. (2003). Education and training for entrepreneurs: A consideration of initiatives in Ireland and The Netherlands. Education + Training, 45, 430-438.

Denzin, N. (1978). The research act. A theoretical introduction to sociological methods. New York: Mc Graw Hill.

Dillman, D.A. (1978). Mail and Telephone Surveys: The Total Design Method. New York, NY: John Wiley \& Sons.

Echtner, C. M. (1995). Entrepreneurial training in developing countries. Annals of Tourism Research, 22(1), 119-134.

Enterprise General Direction (2008). Survey of entrepreneurship in higher education in Europe. Main report. Brussels: European Commission.

Ertuna, Z., \& Gurel, E. (2011). The moderating role of higher education on entrepreneurship. Education+Training, 53(5), 387-402.

Fayolle, A., Gailly, B. \& Lassas-Clerc, N. (2006). Assessing the impact of entrepreneurship education programmes: a new methodology. Journal of European Industrial Trainin, $g$ 30(9), 701-720.

Fidgeon, P. (2010). Tourism education and curriculum design: a time for consolidation and review? Tourism Management, 31(6), 699-723

Garavan, T. N., \& O'Cinneide, B. (1994). Entrepreneurship education and training programmes: A review and evaluation. Part I. Journal of European Industrial Training, $18,3-12$. 
Guerrero, M., \& Urbano, D. (2012). The development of an entrepreneurial university. Journal of Technology Transfer, 37(1), 43-74.

Healy, M. (2005). Linking research and teaching: exploring disciplinary spaces and the role of inquiry-based learning.In Barnett, R. (ed.) Reshaping the University: New Relationships between Research, Scholarship and Teaching (67-78). Maidenhead: McGraw Hill/Open University Press.

Israeli, A. (2014). An inter-paradigmatic agenda for research, education and practice in hospitality management. International Journal of Hospitality Management, 42(3), 188191.

Kibler, E., Kautonen, T. \& Fink M. (2014). Regional Social Legitimacy of Entrepreneurship: Implications for Entrepreneurial Intention and Start-up Behaviour, Regional Studies, 48 (6), 995-1015.

Koh, K. (1995). Designing the four-year tourism management curriculum: a marketing approach. Journal of Travel Research, 33(1), 68-72.

Kolvereid, L. (1996). Prediction of employment status choice intentions. Entrepreneurship Theory and Practice, 21(1), 47-57.

Laukkanen, M. (2000). Exploring alternative approaches in high-level entrepreneurship education: creating micro-mechanisms for endogenous regional growth. Entrepreneurship and Regional Development, 12(1), 25-47.

Li. L. (2008). A review of entrepreneurship research published in the hospitality and tourism management journals. Tourism Management, 29, 1013-1022.

Liñán, F. (2008). Skill and value perceptions: how do they affect entrepreneurial intentions? International Entrepreneurship and Management Journal, 4(3), 257-72.

Liñán, F., \& Chen, Y. (2009). Development and cross-cultural application of a specific instrument to measure entrepreneurial intentions. Entrepreneurship Theory and Practice, 33, 593-617.

Morris, M., Webb, J., Fu, J. \& Singhal S. (2013). A Competency-Based Perspective on Entrepreneurship Education: Conceptual and Empirical Insights. Journal of Small Business Management, 51(3), 352-369.

Nabi, G., \& Holden, R. (2008). Graduate entrepreneurship: intentions, education and training. Education + Training, 50(7), 545-51.

Nicolau, N., \& Shane, S. (2009). Can genetic factors influence the likelihood of engaging in entrepreneurial activity? Journal of Business Venturing, 24, 1-22.

Oh, H., Fiore, A. M., \& Jeoung, M. (2007). Measuring experience economy concepts: Tourism applications. Journal of Travel Research, 46(2), 119-132.

Peterman, N.E., \& Kennedy, J. (2003). Enterprise Education: Influencing Students' Perceptions of Entrepreneurship. Entrepreneurship Theory and Practice, 28, 129-144.

Pittaway, L., Hannon, P., Gibb, A., \& Thompson, J. (2009). Assessment practice in enterprise education. International Journal of Entrepreneurial Behaviour and Research, 15, 71-93.

Rae, D. (2005). Entrepreneurial learning: A narrative based conceptual model. Journal of Small Business and Enterprise Development, 12, 323-335.

Rasmussen, E. A., \& Sorheim, R. (2006). Action-based entrepreneurship education. Technovation, 26, 185-194.

Rodríguez, X, Martínez-Roget, F., \& Pawlowska, E. (2012). Academic tourism demand in Galicia, Spain. Tourism Management, 33(6), 1583-1590.

Saarinen, T., \& Ursin, J. (2012). Dominant and emerging approaches in the study of higher education policy change. Studies in Higher Education, 37(2), 143-156. 
Sanchez, J.C. (2013). The Impact of an Entrepreneurship Education Program on Entrepreneurial Competencies and Intention. Journal of Small Business Management, 51(3), 447-465.

Shapero, A., \& Sokol, L. (1982). The social dimension of entrepreneurship. In C. A. Kent, D. L. Sexton and K. H. Vesper (Eds.), Encyclopedia of entrepreneurship (72-90). Englewood Cliffs, NJ: Prentice Hall.

Solvoll, S., Alsos, G. A., \& Bulanova O. (2015). Tourism Entrepreneurship - Review and Future Directions. Scandinavian Journal of Hospitality and Tourism, 15(1), 120-137.

Souitaris, V., Zerbinati, S., \& Al-Laham, A. (2007). Do entrepreneurship programmes raise entrepreneurial intention of science and engineering students? The effect of learning, inspiration and resources. Journal of Business Venturing, 22, 566-591.

Tribe, J. (1997). The indiscipline of tourism. Annals of Tourism Research, 24, 638-657.

Tribe, J. (2000a). Indisciplined and unsubstantiated: reply to Leiper. Annals of Tourism Research, 29(2), 338-357.

Tribe, J. (2000b). Balancing the vocational: the theory and practice of liberal education in tourism. The International Journal of Tourism and Hospitality Research, 2(1), 9-26.

Tribe, J. (2002). The philosophic practitioner. Annals of Tourism Research, 29, 38-357.

Zagonari, F. (2009). Balancing tourism education and training. International Journal of Hospitality Management, 28(1), 2-9. 
Figure 1: Tourism education and entrepreneurship vocation

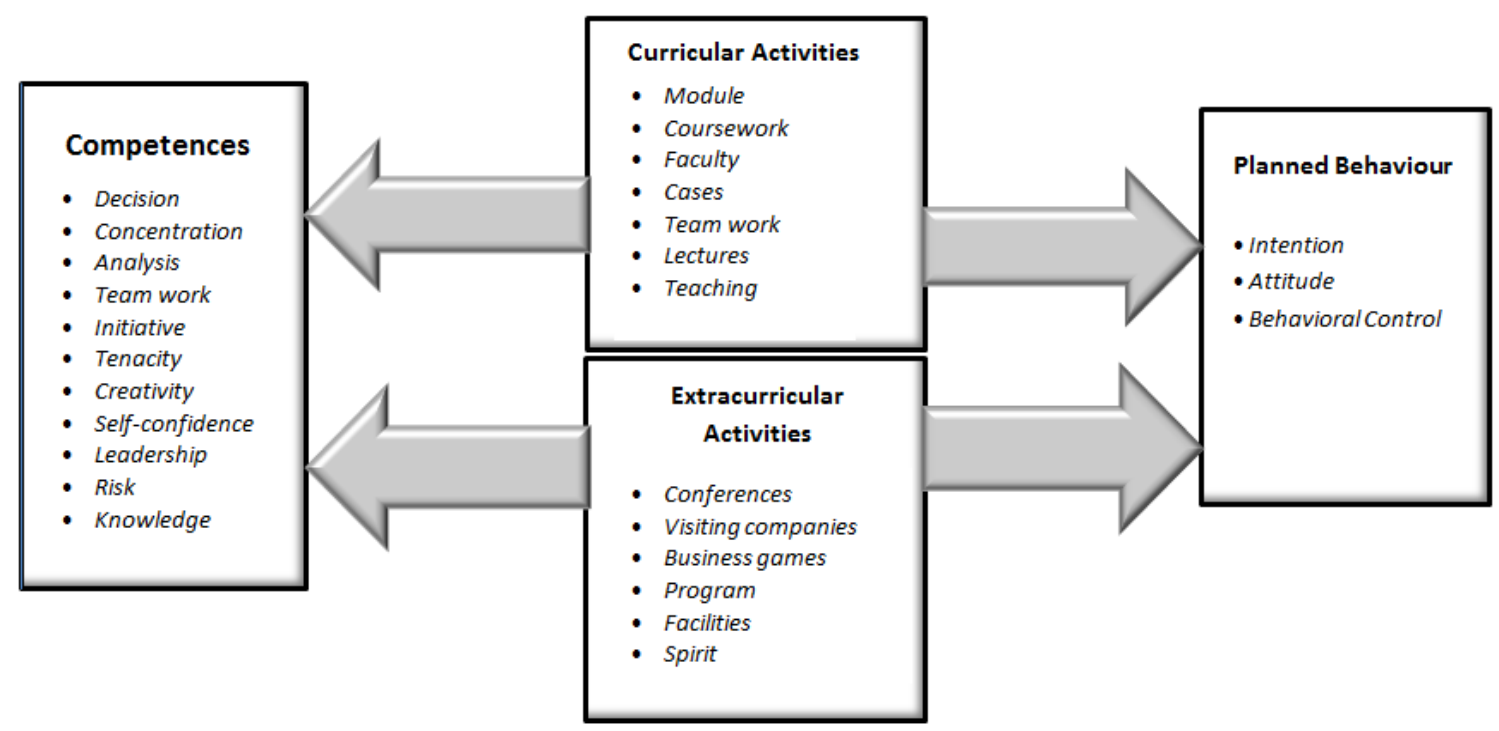

Table 1. Intention, Attitude and Behavioural Control

\begin{tabular}{llllll}
\hline & Descriptive Statistics & \multicolumn{4}{c}{ MANOVA } \\
Variables & Level & Mean & Std. Deviation & F & Sig. \\
\hline \multirow{2}{*}{ Behavioural Control } & Undergraduate & 4.4105 & 1.75944 & 2.199 & 0.141 \\
& Master & 3.8148 & 2.11291 & & \\
\multirow{2}{*}{ Intention } & Undergraduate & 3.0000 & 1.63733 & 0.630 & 0.429 \\
& Master & 3.2963 & 1.95753 & & \\
Attitude & Undergraduate & 5.1579 & 1.47544 & 0.856 & 0.357 \\
& Master & 4.8519 & 1.65724 & & \\
\hline
\end{tabular}

Table 2. Curricular activities

\begin{tabular}{|c|c|c|c|c|c|}
\hline \multirow[b]{2}{*}{ Variables } & \multicolumn{3}{|c|}{ Descriptive Statistics } & \multicolumn{2}{|c|}{ MANOVA } \\
\hline & Level & Mean & Std. Deviation & $\mathbf{F}$ & Sig. \\
\hline \multirow{3}{*}{ Module } & Undergraduate & 5.5579 & 1.37389 & \multirow{2}{*}{.747} & \multirow{2}{*}{.389} \\
\hline & Master & 5.2963 & 1.43620 & & \\
\hline & Undergraduate & 5.4211 & 1.38056 & \multirow{2}{*}{.442} & \multirow{2}{*}{.508} \\
\hline \multirow[t]{2}{*}{ Courseworks } & Master & 5.2222 & 1.33973 & & \\
\hline & Undergraduate & 5.6526 & 1.35873 & \multirow{2}{*}{.906} & \multirow{2}{*}{.343} \\
\hline \multirow[t]{2}{*}{ Faculty } & Master & 5.3704 & 1.36292 & & \\
\hline & Undergraduate & 4.5684 & 1.35782 & \multirow[t]{2}{*}{2.365} & \multirow[t]{2}{*}{.127} \\
\hline \multirow[t]{2}{*}{ Cases } & Master & 5.0370 & 1.53125 & & \\
\hline & Undergraduate & 4.4000 & 1.54644 & \multirow{2}{*}{1.727} & \multirow{2}{*}{.191} \\
\hline \multirow[t]{2}{*}{ Team work } & Master & 4.8519 & 1.68029 & & \\
\hline & Undergraduate & 4.2526 & 1.83910 & 3.577 & .061 \\
\hline \multirow[t]{2}{*}{ Entrepreneurial Lectures } & Master & 5.0000 & 1.70970 & \multirow{3}{*}{.005} & \multirow{3}{*}{.946} \\
\hline & Undergraduate & 4.7158 & 1.70521 & & \\
\hline Teaching methodology & Master & 4.7407 & 1.67774 & & \\
\hline
\end{tabular}


Table 3. Extra-curricular activities

\begin{tabular}{lllcrr}
\hline \multirow{2}{*}{ Variables } & Descriptive Statistics & & \multicolumn{2}{c}{ MANOVA } \\
& Level & Mean & Std. Deviation & F & Sig. \\
\hline \multirow{2}{*}{ Entrepreneurial conferences and } & Undergraduate & 5.5263 & 1.45018 & 2.612 & .107 \\
seminars & Master & 4.5556 & 2.10006 & & \\
& Undergraduate & 5.4105 & 1.40284 & 1.778 & .301 \\
Visiting companies & Master & 4.2963 & 2.01561 & & \\
& Undergraduate & 5.6211 & 1.43793 & 1.450 & .226 \\
Business games & Master & 3.6667 & 2.07550 & & \\
& Undergraduate & 4.5263 & 1.42800 & 3.098 & .081 \\
Programme & Master & 3.9259 & 1.97924 & & \\
& Undergraduate & 4.3895 & 1.55942 & 1.436 & .233 \\
Facilities and infrastructure & Master & 3.9630 & 1.87045 & & \\
& Undergraduate & 4.2105 & 1.89003 & 2.468 & .119 \\
Spirit and values university & Master & 3.5556 & 1.98714 & & \\
\hline
\end{tabular}

Table 4. Entrepreneurial Competencies

\begin{tabular}{|c|c|c|c|c|c|}
\hline \multirow[t]{2}{*}{ Descriptive Statisti } & \multirow[b]{2}{*}{ Level } & \multirow[b]{2}{*}{ Mean } & \multirow[b]{2}{*}{$\begin{array}{c}\text { Std. } \\
\text { Deviation }\end{array}$} & \multicolumn{2}{|c|}{ MANOVA } \\
\hline & & & & $\mathbf{F}$ & Sig. \\
\hline \multirow{3}{*}{ Power of decision about my business project (Decision) } & Undergraduate & 5.5158 & 1.21920 & \multirow[t]{3}{*}{3.348} & \multirow[t]{3}{*}{.062} \\
\hline & Master & 4.8148 & 1.88184 & & \\
\hline & Undergraduate & 5.4000 & 1.34797 & & \\
\hline $\begin{array}{l}\text { Effort and concentration until achieving success } \\
\text { (Concentration) }\end{array}$ & Master & 5.0000 & 1.77591 & 1.597 & .209 \\
\hline \multirow{3}{*}{ Analysing the diverse solutions(Analysis) } & Undergraduate & 4.9263 & 1.33880 & \multirow[t]{2}{*}{.015} & \multirow[t]{2}{*}{.904} \\
\hline & Master & 4.9630 & 1.55617 & & \\
\hline & Undergraduate & 4.8632 & $\begin{array}{l}1.44848 \\
1.54701\end{array}$ & \multirow{2}{*}{.530} & \multirow[t]{2}{*}{.468} \\
\hline Work in groups (Team work) & & 4.6296 & & & \\
\hline \multirow{2}{*}{ Taking the initiative, defining goals (Initiative) } & $\begin{array}{l}\text { Undergraduate } \\
\text { Master }\end{array}$ & $\begin{array}{l}5.1368 \\
4.7407\end{array}$ & $\begin{array}{l}1.41880 \\
1.87273\end{array}$ & \multirow[t]{2}{*}{1.412} & \multirow[t]{2}{*}{.237} \\
\hline & Undergraduate & 5.4842 & 1.25362 & & \\
\hline \multicolumn{2}{|c|}{$\begin{array}{l}\text { Working as long as is necessary to finish the project Master } \\
\text { (Tenacity) }\end{array}$} & 5.1111 & 1.69464 & 1.579 & .211 \\
\hline \multirow{3}{*}{ New ways to make things (Creativity) } & Undergraduate & 5.3053 & 1.22104 & \multirow[t]{2}{*}{3.238} & \multirow[t]{2}{*}{.074} \\
\hline & Master & 4.7778 & 1.71718 & & \\
\hline & Undergraduate & 4.7895 & 1.55669 & \multirow{2}{*}{1.063} & \multirow{2}{*}{.305} \\
\hline \multirow[t]{2}{*}{ Self-confidence (Self-confidence) } & Master & 4.4444 & 1.45002 & & \\
\hline & Undergraduate & 5.0526 & 1.25790 & \multirow{2}{*}{1.267} & \multirow{2}{*}{.263} \\
\hline $\begin{array}{l}\text { Leadership to convince and make people joining your } \\
\text { project (Leadership) }\end{array}$ & Master & 4.7037 & 1.89767 & & \\
\hline \multirow[b]{2}{*}{ You like to take risks (Risk) } & Undergraduate & 4.2737 & & \multirow{2}{*}{.080} & \multirow{2}{*}{.778} \\
\hline & Master & 4.3704 & 1.66752 & & \\
\hline $\begin{array}{l}\text { Necessary education to undertake } \\
\text { (Knowledge) }\end{array}$ & $\begin{array}{l}\text { Undergraduate } \\
\text { Master }\end{array}$ & $\begin{array}{l}3.7368 \\
3.5556\end{array}$ & $\begin{array}{l}1.62566 \\
1.69464\end{array}$ & .257 & .613 \\
\hline
\end{tabular}


Table 7. SEM Curricula Activities/Competencies (Chi-square $=533.434$; Degrees of freedom $=110 ;$ Probability level $=.000)$

\begin{tabular}{lclrrrr}
\hline \hline Competencies & Curricula Activities & Estimate & S.E. & C.R. & P \\
\hline Decision & $<---$ & Module & .289 & .099 & 2.910 & .004 \\
Decision & $<---$ & Faculty & .133 & .101 & 1.313 & .189 \\
Leadership & $<---$ & Module & .203 & .101 & 2.008 & .045 \\
Leadership & $<---$ & Faculty & .222 & .112 & 1.983 & .047 \\
Leadership & $<---$ & Groups & .180 & .089 & 2.036 & .042 \\
Leadership & $<---$ & Methodology & -.181 & .091 & -1.994 & .046 \\
Teamwork & $<---$ & Module & .191 & .097 & 1.969 & .049 \\
Teamwork & $<--$ & Faculty & .257 & .107 & 2.396 & .017 \\
Teamwork & $<---$ & Groups & .347 & .085 & 4.088 & $* * *$ \\
Teamwork & $<---$ & Methodology & -.185 & .087 & -2.125 & .034 \\
Concentration & $<---$ & Courseworks & .360 & .091 & 3.964 & $* * *$ \\
Analysis & $<---$ & Faculty & .223 & .092 & 2.413 & .016 \\
Analysis & $<---$ & Groups & .179 & .079 & 2.257 & .024 \\
Initiative & $<---$ & Module & .267 & .097 & 2.737 & .006 \\
Tenacity & $<---$ & Module & .217 & .090 & 2.414 & .016 \\
Tenacity & $<---$ & Groups & .142 & .079 & 1.807 & .071 \\
Creativity & $<---$ & Groups & .197 & .076 & 2.592 & .010 \\
Selfconfidence & $<---$ & Faculty & .267 & .098 & 2.712 & .007 \\
Selfconfidence & $<---$ & Lectures & .170 & .073 & 2.326 & .020 \\
Risk & $<---$ & Groups & .296 & .100 & 2.961 & .003 \\
Knowledge & $<---$ & Groups & .365 & .088 & 4.153 & $* * *$ \\
Risk & $<---$ & Methodology & -.146 & .093 & -1.564 & .118 \\
\hline & & & & & &
\end{tabular}


Table 8. SEM Extra-curricular Activities/Competencies (Chi-square $=686.417$; Degrees of freedom $=113 ;$ Probability level $=.000$ )

\begin{tabular}{lrlrrrr}
\hline \hline Competencies & \multicolumn{1}{c}{ Extra-curricular Activities } & Estimate & S.E. & C.R. & P \\
\hline Decision & $<---$ & Conferences & .332 & .071 & 4.645 & $* * *$ \\
Leadership & $<---$ & Conferences & .211 & .076 & 2.783 & .005 \\
Teamwork & $<---$ & Conferences & .216 & .079 & 2.741 & .006 \\
Teamwork & $<---$ & Facilities & .147 & .080 & 1.839 & .066 \\
Initiative & $<---$ & Conferences & .253 & .083 & 3.055 & .002 \\
Initiative & $<---$ & Spirit & -.094 & .071 & -1.325 & .185 \\
Tenacity & $<---$ & Conferences & .123 & .076 & 1.624 & .104 \\
Tenacity & $<---$ & Facilities & .106 & .077 & 1.377 & .168 \\
Creativity & $<---$ & Spirit & -.084 & .064 & -1.317 & .188 \\
Selfconfidence & $<---$ & Games & .109 & .082 & 1.319 & .187 \\
Selfconfidence & $<---$ & Spirit & .105 & .077 & 1.378 & .168 \\
Knowledge & $<---$ & Program & -.199 & .106 & -1.883 & .060 \\
Knowledge & $<---$ & Facilities & .335 & .102 & 3.281 & .001 \\
\hline
\end{tabular}

Figure 2. Entrepreneurial vocation of young university students in the tourism sector

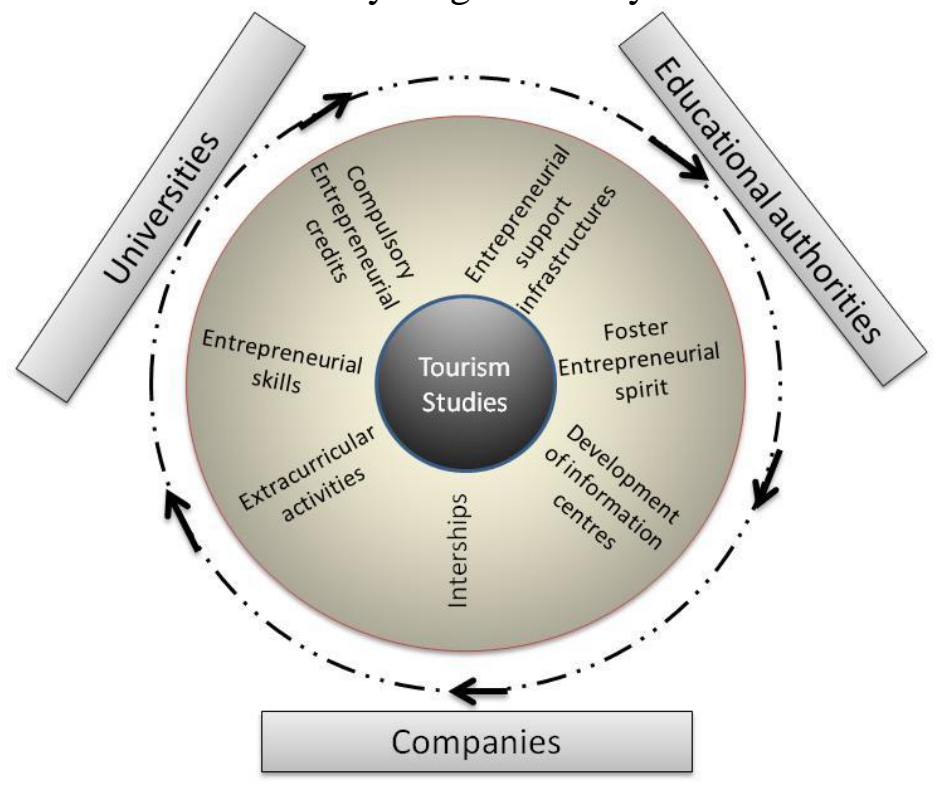


Table 5. Correlation between curricular activities and competencies

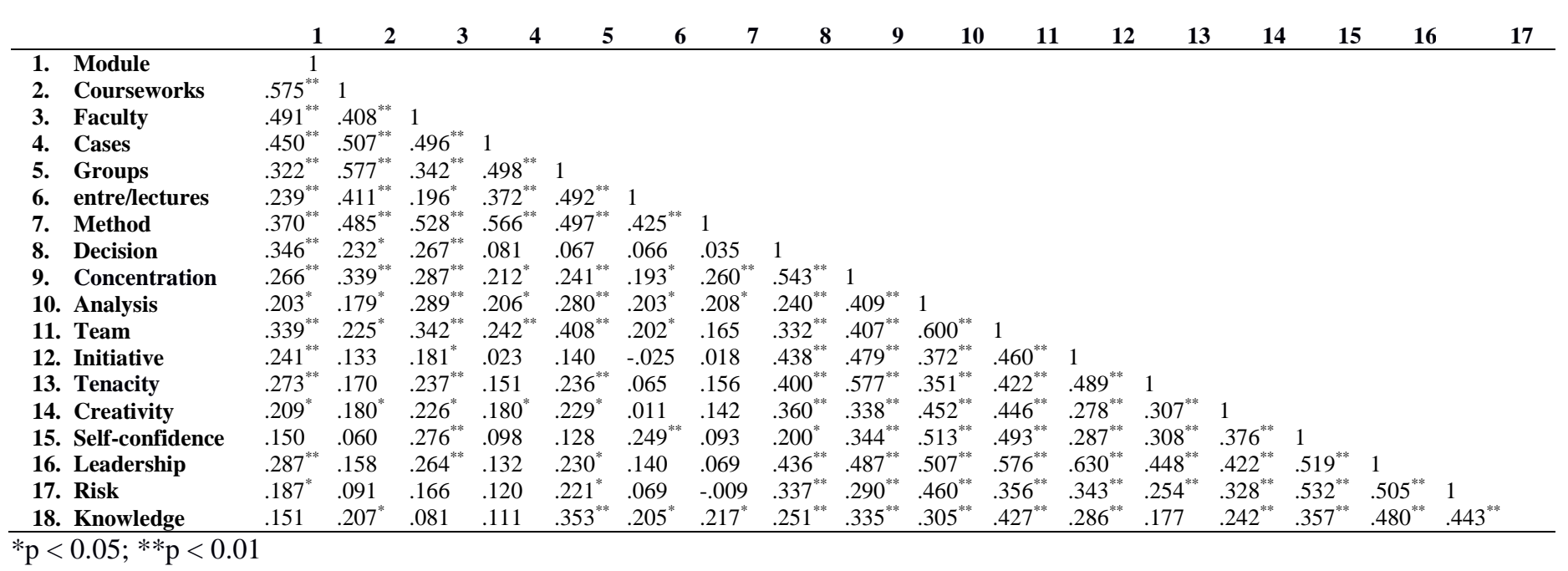

Table 6. Correlation between extra-curricular activities and competencies

\begin{tabular}{|c|c|c|c|c|c|c|c|c|c|c|c|c|c|c|c|c|}
\hline & 1 & 2 & 3 & 4 & 5 & 6 & 7 & 8 & 9 & 10 & 11 & 12 & 13 & 14 & 15 & 10 \\
\hline 1. Conferences & 1 & & & & & & & & & & & & & & & \\
\hline 2. Visiting & $.619^{* *}$ & 1 & & & & & & & & & & & & & & \\
\hline 3. Games & $.463^{* *}$ & $.526^{* *}$ & 1 & & & & & & & & & & & & & \\
\hline 4. Program & $.373^{* *}$ & $.457^{* *}$ & $.530^{* *}$ & 1 & & & & & & & & & & & & \\
\hline 5. Facilities & $.259^{* *}$ & $.469^{* *}$ & $.422^{* *}$ & $.522^{* *}$ & 1 & & & & & & & & & & & \\
\hline 6. Spirit university & $.214^{*}$ & $.403^{* *}$ & $.379^{* *}$ & $.381^{* * *}$ & $.451^{* *}$ & 1 & & & & & & & & & & \\
\hline 7. Decision & $.389^{* *}$ & $.270^{* *}$ & $.225^{*}$ & .121 & .047 & .070 & 1 & & & & & & & & & \\
\hline 8. Concentration & $.206^{*}$ & $.263^{* *}$ & $.200^{*}$ & $.202^{*}$ & .166 & .140 & $.543^{* *}$ & 1 & & & & & & & & \\
\hline 9. Analysis & .103 & .108 & $.179^{*}$ & .152 & .162 & .086 & $.240^{* *}$ & $.409^{* *}$ & 1 & & & & & & & \\
\hline 10. Team & $.286^{* *}$ & .170 & .149 & .122 & $.227^{*}$ & .054 & $.332^{* *}$ & $.407^{* * *}$ & $.600^{* *}$ & 1 & & & & & & \\
\hline 11. Initiative & $.248^{* *}$ & .157 & .117 & .084 & .113 & -.060 & $.438^{* *}$ & $.479^{* *}$ & $.372^{* *}$ & $.460^{* *}$ & 1 & & & & & \\
\hline 12. Tenacity & $.182^{*}$ & .093 & .101 & .076 & .165 & .043 & $.400^{* *}$ & $.577^{* *}$ & $.351^{* * *}$ & $.422^{* *}$ & $.489^{* *}$ & 1 & & & & \\
\hline 13. Creativity & .139 & .136 & .030 & .100 & .057 & -.119 & $.360^{* *}$ & $.338^{* *}$ & $.452^{* *}$ & $.446^{* * *}$ & $.278^{* *}$ & $.307^{* *}$ & 1 & & & \\
\hline 14. Self-confidence & .058 & .042 & .177 & .030 & .050 & $.180^{*}$ & $.200^{*}$ & $.344^{* *}$ & $.513^{\text {** }}$ & $.493^{* *}$ & $.287^{* *}$ & $.308^{* *}$ & $.376^{* *}$ & 1 & & \\
\hline 15. Leadership & $.245^{* *}$ & .145 & $.181^{*}$ & $.203^{*}$ & $.213^{*}$ & .052 & $.436^{* *}$ & $.487^{* *}$ & $.507^{* *}$ & $.576^{* * *}$ & $.630^{* *}$ & $.448^{* *}$ & $.422^{* *}$ & $.519^{* * *}$ & 1 & \\
\hline 16. Risk & .031 & -.036 & .021 & .036 & .095 & -.040 & $.337^{* *}$ & $.290^{* * *}$ & $.460^{* *}$ & $.356^{* *}$ & $.343^{* *}$ & $.254^{* * *}$ & $.328^{* *}$ & $.532^{* *}$ & $.505^{* *}$ & 1 \\
\hline 17. Knowledge & .084 & .131 & .068 & -.017 & $.235^{* *}$ & .119 & $.251^{* *}$ & $.335^{* *}$ & $.305^{* *}$ & $.427^{* *}$ & $.286^{* *}$ & .177 & $.242^{* *}$ & $.357^{* *}$ & $.480^{* *}$ & $.443^{* *}$ \\
\hline
\end{tabular}

